\title{
DIFFERENT MEANINGS A TEXT MAY ACQUIRE: THE CASE OF MALACHI 1:11
}

\author{
S.D. Snyman ${ }^{1}$
}

\begin{abstract}
This article illustrates how a text may acquire different meanings over years of investigation. On the basis of Malachi 1:11, the article demonstrates how this text was interpreted from various perspectives. Historical interpretation attempts to locate the meaning of the text either in the historical circumstances at the time of the origin of the text or at some undefined future time. A literary interpretation does not attempt to locate the text in history but rather tries to interpret it either as a hyperbole or metaphorically or by means of an intertextual investigation. At least eight different meanings were detected.
\end{abstract}

\section{INTRODUCTION}

There is no need to doubt that Malachi 1:11 presents the exegete with various problems. Deissler (1988:322), for instance, remarked: "Dieser Vers gehört zu den umstrittensten Texten der Bibel", and Reventlow (1993:141) stated: "Dieser Vers ist der meistdiskurierte des ganzes Buches". It is interesting to note how the meaning ascribed to this text has shifted over the years. The change of meaning ascribed to the text is also related to the approach followed in the exegesis of the text.

It is beyond the scope of this article to present a comprehensive exegesis of Malachi 1:11 in its literary and historical context. The crux interpretum of verse 11 is to find an answer to the question of to whom the people are bringing the pure offerings "in every place"? Various ingenious answers have been given to this question in the course of the history of the investigation of this book. The various attempts can be categorised into two main groups. The majority of scholars follow a historical approach, trying to locate the solution to the problem in history, either in the time of the prophet or in some future

1 Prof. S.D. (Fanie) Snyman, Head: Department of Old Testament, Faculty of Theology, University of the Free State, P.O. Box 339, Bloemfontein, 9300. E-mail: snymansd.hum@mail.uovs.ac.za. 
time. On the other hand, some scholars follow a literary approach by focusing on the literary features of the text.

\section{READING THE TEXT}

Any investigation of a text starts by reading the text. It is always useful to consult a number of translations of a text. Malachi 1:11 has been translated as follows:

${ }^{11}$ For from the rising of the sun even unto the going down of the sun my name shall be great among the Gentiles; and in every place incense shall be offered unto my name, and a pure offering: for my name shall be great among the heathen, saith the LORD of hosts. $(K J V$.

For from the rising of the sun, even to its going down, My name shall be great among the Gentiles;

In every place incense shall be offered to My name,

And a pure offering;

For My name shall be great among the nations,

Says the LORD of hosts. (NKJV.)

${ }^{11}$ For from the rising of the sun to its setting my name is great among the nations, and in every place incense is offered to my name, and a pure offering; for my name is great among the nations, says the LORD of hosts. (NRSV.)

${ }^{11} \mathrm{My}$ name will be great among the nations, from the rising to the setting of the sun. In every place incense and pure offerings will be brought to my name, because my name will be great among the nations, says the LORD Almighty. (NIV.)

But my name is honored by people of other nations from morning till night. All around the world they offer sweet incense and pure offerings in honor of my name. For my name is great among the nations, says the LORD Almighty. (NLT.)

${ }^{11}$ For from the rising of the sun, even to its setting, my name is great among the nations;

And everywhere they bring sacrifice to my name, and a pure offering;

For great is my name among the nations, says the LORD of hosts. (NAB.)

${ }^{11}$ People from one end of the world to the other honour me. Everywhere they burn incense to me and offer acceptable sacrifices. All of them honour me! (GNB.)

${ }^{11}$ From dawn until dusk my name is praised by every nation on this earth, as they burn incense and offer the proper sacrifices to me. $(C E V$. 
A comparison of these translations reveals some interesting differences. In both the New Living Translation and the Contemporary English Version the first phrase of the text gives an indication of time ("from morning till night"; "from dawn till dusk") whereas the other translations give an indication of space ("everywhere"; "from the rising of the sun even to its setting"). The second notable difference is the translation of the middle section of the verse. Some translations render the text in the future tense $(K J V, N K J V, N I V)$ whereas the other translations use the present tense. A third difference is the rendering of the phrase "among the nations" בגוים. Should it be translated as "every nation" (CEV), as "by people of other nations" (NLT), or as "among the nations" as is the case in most of the other translations?

The Hebrew text reads as follows:

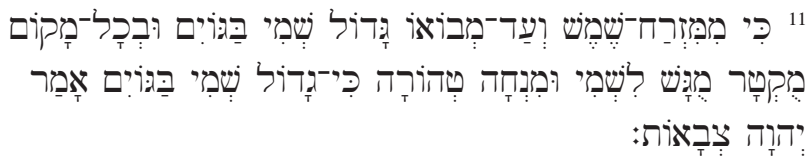

(BHS)

Verse 11 starts with which immediately raises the question what kind of is meant in this instance. The particle $כ$ can be understood in a causal sense ("because") meaning that verse 11 provides the reason why Yahweh has no pleasure in the offerings the people bring - his name is great among the nations and everywhere pure offerings are brought to honour him. Verse 11 concludes the argument of verses 6-10 with the implication that Yahweh is not concerned about the malpractices of the priests because $\mathrm{He}$ is honoured sufficiently elsewhere by the pure offerings brought to Him. But that is not the point. Yahweh wants to be honoured and worshipped in the correct and prescribed manner by his people; that is why the prophet rebukes the priests. Another possibility is to treat $כ$ as a particle of assertion, meaning "yes" or "indeed". This would imply a new turn in the argument. Verse 11 provides a new perspective to the argument thus far. It answers the question of what will happen when the sacrifices cease in the temple as implied in verse 10 . The proposal by Petersen $(1995: 174,176)$ to read כממזרח instead of כי ממזרח seems 
unnecessary; it has no support from the manuscripts and does not significantly enhance the meaning of the text.

The next phrase "from [the place] where the sun rises to where the sun sets my name is great among the nations" is an expression of space indicating the vastness and extent of Yahweh's reign rather than (day-)time (contra NLT and CEV). This phrase is also used in Psalms $(50: 1 ; 113: 3)$, the prophetic literature (Is $45: 6 ; 59: 19)$ as well as in extra-Biblical literature such as the Amarna letters (288) and the Mari letters (Verhoef 1987:224; Stuart 1998:1306). The latter section of the phrase - "my name is great among the nations" — occurs twice in the verse creating an inclusio around the middle part (and the most problematic part as well) of the verse. This structuring also indicates that the middle section of the verse constitutes the essence of this saying. The emphasis is not on the nations per se, but rather on the greatness of Yahweh's name among the nations. Yahweh's name is great among the nations; this verse does not imply that Yahweh's name is made great by the nations.

The middle section of verse 11 is controversial. Its grammar is atypical (two hophal participles next to each other, מקטר מגש), but not impossible. Most scholars take the first hophal participle as a substantive and the second one as a verb, thus, "and in every place incense/burnt offering (מקטר) is brought (מגשי) to my name - a pure offering". The term מקטר is a general one indicating offerings that are burnt, the root קטר meaning the rise of smoke coming from a sacrifice (Lev 1:9; 2:11; 6:15;8:21), hence the alternative translation of "incense" or "burnt offering". The verb נגשי, bringing an offer, is familiar in this pericope (verse 7 and twice in verse 8 ) and also occurs in the remaining section of the book $(2: 12 ; 3: 3)$. Two final comments on the last section of the much disputed ומנחה טהורה. The root refers to cultic purity. This is the only case in the Old Testament where it is used for offerings. Secondly, the waw copula with ומנחה is taken as a waw epexegeticum (Van der Woude) or waw emphaticum (Swetnam); ומנחה טהורה is therefore translated as a final interjection, emphasising and intensifying the idea of the kind of offerings brought — not any kind of offering; but pure offerings. 
There are few text-critical problems in the text. According to $B H S$, verses $11-13$ can be considered a later addition to the text and some scholars (Elliger 1975:195; Horst 1964:265; Botterweck 1960: 100-101) support this point of view. There is no proof from other manuscripts to substantiate such a claim.

\section{HISTORICAL INTERPRETATIONS OF MALACHI 1:11}

Scholars follow two main lines of historical interpretation. Some interpret the text as referring to conditions current at the time of the prophet, whereas others interpret the text as a reference to the future and therefore adhere to an eschatological interpretation of the text.

\subsection{Malachi 1:11 as a reference to a situation current at the time of the prophet}

\subsubsection{Sacrifices offered by the nations}

Some scholars (G.A. Smith 1943:351; Horst 1964:267; Frey 1963: 148) were of the opinion that (pagan) nations brought pure offerings to honour Yahweh. According to them, there was in the time of the prophet a general shift towards a universal monotheistic worship, in particular the Persian era (Horst 1964:267). This (interpolated) saying (definitely not the prophet Malachi!) was clearly in line with this trend. G.A. Smith (1943:351), for instance, states that verse 11 does not merely teach that there are decent and righteous people in every nation, but that the sacrifices of the heathen are pure and acceptable to Him. This theory dates back as far as Theodore of Mopsuetia who claimed that even in serving idols, the pagans were worshipping God (Verhoef 1987:226).

Although this view was held by many scholars in the $20^{\text {th }}$ century, - Verhoef (1987:227) refers to this as an "almost universally accepted theory" and Rehm (1961:200) quotes a number of commentaries from the $19^{\text {th }}$ century supporting this view - few scholars would support this view today. Other texts (Malachi 1:2-5; 2:11-12; 3:4) militate against the idea of a universal worship of Yahweh. It is unthink- 
able that a monotheistic religion such as the Yahwism of that time would blend in with a supposedly universal monotheistic worship of religions in the Persian era. The text explicitly states that pure offerings are brought "to my name", making it improbable that other gods could be worshipped and that this could be considered worshipping Yahweh incognito. Furthermore, there is no reference in the Old Testament that offerings by pagans or heathens are acceptable or pleasing to Yahweh. Rudolph (1976:263) notes that the idea of pagan or heathen sacrifices brought in sincerity to their gods while being perfectly acceptable to Yahweh, would contravene the first commandment. Rudolph's (1976:263) solution to this problem is that the prophet made his claim on the basis of concrete experiences in this regard, but that we no longer have access to these experiences. The problem with this point of view is that it is basically an argument from silence which is always difficult to prove.

\subsubsection{Sacrifices offered by Jewish proselytes}

A second opinion on this subject is that Jewish proselytes brought the pure offerings. This is a slight modification of the previous solution to the problem. Gentiles, but only those who converted to become Jewish proselytes, are bringing pure offerings. Vriezen (1975) is a (hesitant) proponent of this view. According to him Malachi has a broad concept of God considering the many ways in which Yahweh is pictured in the book (Yahweh, El, Father, Lord). According to Vriezen the prophet lived in the expectation of the nearness of the revelation of God's kingdom and in the certainty of the visible spreading of the acknowledgement of Israel's Lord by the nations. Vriezen (1975:134) concludes that the nations may have started to worship Yahweh not only in syncretistic form. Recently converted gentiles would certainly have performed the rites of the cult of Yahweh in all earnestness. Verse 11 indicates that Yahweh's name receives pure sacrifices from many unexpected places. Yahweh does not dependent on the offerings of Jerusalem.

There are two main objections to this opinion. First, the text does not provide evidence that the people bringing the pure offerings are converted gentiles. It does not tell us who the people are that bring the offerings. The other phrases in the text simply speak of Yahweh's 
name that is great "among the nations" (בגוים). Secondly, it is questionable whether there were large numbers of gentiles converted to Yahwism in the $5^{\text {th }}$ century BCE. At that time Judah was a minor part of the Persian Empire, and people would have no reason to convert to the God of a subjected nation.

\subsubsection{Sacrifices offered by the Jews in the Diaspora}

Scholars put forward a third possibility, namely the Jews in the Diaspora. There were too few proselytes to serve as a basis for a claim to a worldwide acknowledgement of Yahweh; Jews were spread across the Persian Empire, from Babylonia and Persia in the East to parts of Southern Egypt in the West. Jewish colonies in Elephantine and possibly also in Leontopolis (Josephus, Antiquenes 13.3.1; par 65-8), Samaria and the Transjordan are well known and not all exiles living in Babylonia returned to the land in 538 BCE. Weyde (2000:149) notes a well-documented custom of Jews bringing offerings to Yahweh in other countries. At least, this verse opens up the possibility of proper worship of Yahweh beyond Jerusalem and the temple (Petersen 1995:184). According to Smith (1980:31), the allusion to the widely dispersed Jewish community beyond the borders of the country, is the most probable interpretation of this verse. This is also the conclusion of Utzschneider (1989:54-57, 84-87) who investigated intertextual relations between Malachi 1:11, Ezekiel 36 and Psalm 113:3-4.

The objection raised to this possibility is that the worship of Yahweh, in particular in Elephantine, was probably of a syncretistic kind, and would not serve the purpose of the present argument. Secondly, there is also the lack of clear textual evidence. Thirdly, according to Viberg (1994:303), the sacrifices are not only offered among the nations but are presented by them as "is clearly implied by the text". The point of the passage, according to Viberg (1994:303), is the contrast between the priests and the nations. However, Viberg's argument is not convincing. The text does not mention that offerings were brought by the nations. To claim that this "is clearly implied by the text" is rather Viberg's own interpretation. As noted earlier, interpreting the meaning of the phrase בגוים as "among the nations" differs from interpreting it as meaning "by the nations". The contrast is not so much between the priests and the nations, but rather between pro- 
per worship beyond Jerusalem and the temple and improper worship allowed and practised by the priests in the temple in Jerusalem.

\subsection{Eschatological interpretations of Malachi 1:11}

What is proclaimed in Malachi 1:11 cannot be proven, either in the Jewish community or in the gentile world. This conclusion prompted scholars to consider the possibility that Malachi 1:11 refers to the future and that it must be explained in an eschatological sense.

\subsubsection{The interpretation by the Roman Catholic Church}

Already during the first half of the $2^{\text {nd }}$ century CE there was a connection made between this verse and the Lord's Supper. The Didache mentions that sin must be confessed so that your sacrifice may be pure (Rehm 1961:203). It has been documented that the Roman Catholic Church found its principal proof-text for the doctrine of the Holy Mass in the "pure offering" of 1:11. In this sense the text is an anticipation of a ritual sacrifice of the Messianic age that will fulfil and perfect the Mosaic rite. This text's interpretation is thus not restricted to the time of the prophet, but rather to a future Messianic age (Smith 1984:313-314).

\subsubsection{An eschatological interpretation}

Problems confronting scholars who interpret a text contemporaneous with the time of the prophet, caused them to interpret verse 11 from an eschatological perspective. Calvin (1979:500) interprets the text from an eschatological point of view. God shows that he no longer cared for the Jews and that he would bid altars to be erected for him everywhere and in all parts of the world so that he might be purely worshipped by all nations. God's name would be celebrated throughout the world. Offering and incense mean the worship of God.

This passage states nothing else than that the time would come when the pure and spiritual worship of God would prevail in all places (Calvin 1979:502).

Although Verhoef (1966:169) does not want to reject the previous solutions to the problem, he nevertheless opts for an eschatological 
interpretation. The text cannot be confined to the circumstances of the Jews in the dispersion and to the proselytes

but must also be applied to the situation of the Messianic age, according to the general trend of the prophetical message (Verhoef 1966:169).

A related interpretation is that of Rehm (1961:205) who is of the opinion that the text in question concerns the conversion of the nations as part of the messianic hope. Malachi 1:11 is an utterance from the prophet on the approaching messianic time. When the gentile nations convert to Yahweh they will bring him offerings expressing their respect and honour for him (Rehm 1961:207).

According to Baldwin (1972:122; 1978:228-229), the absence of a verb in the statement that Yahweh is a great king in verse 14 leaves the door open for an eschatological interpretation of this verse. The phrase "from the rising of the sun to its setting" in the Psalms (50:1; 113:3) and in Isaiah (45:6; 59:9) is used in contexts that "look towards an eschatological demonstration of the Lord's person to the whole inhabited world". The hophal participle used may also "announce future actions or events". Moreover, this will be in line with many other prophetic announcements where a time is envisioned when Yahweh would be acknowledged as king and when nations will join themselves to Yahweh (Glazier-McDonald 1987:60-61; Merrill 1994:400). Verse 11 is thus a prediction rather than a description of current events, a future contrast to a present reality (Stuart 1998:1306). Krieg (1993: 146-147) is also in support of an eschatological understanding of the text due to the occurrence of the theme in other parts of the Old Testament, Deutero-Isaiah and some of the Psalms (cf. also Deissler 1988:322-323; Achtemeier 1986:177).

The strength of this view is that it solves the problems of locating this saying in a historical context by projecting the text to the future and therefore undefined context. Objections to an eschatological interpretation are raised mainly on grammatical grounds. Viberg (1994: 305) rightly asks why the prophet expresses his references to the future by means of participles which usually express the present. Swetnam (1969:203) adds another objection: since it is the current state of 
affairs that is criticised the natural inference is that the offerings made outside Jerusalem are also contemporaneous.

\section{LITERARY INTERPRETATIONS}

As the historical interpretations did not meet scholars' expectations, some attempted a literary interpretation of v. 11 .

\subsection{Malachi 1:11 understood as a hyperbole}

According to this interpretation, the focus of the text is not on the sacrifices brought, but rather on the honour Yahweh deserves. The reference to the sacrifices is therefore hyperbolic: the sacrifices brought by the gentiles are pure when compared to the despised offerings brought by the priests (Reventlow 1993:142). The text aims to show a more sincere and dedicated worship than that of the Israelite priests (Viberg 1994:307).

\section{Baldwin (1972:121) agrees that there}

is an element of hyperbole reflecting passionate feeling which goes beyond the facts but to maintain that the prophet would not have stood his statement if pressed is a dangerous assumption which cannot be allowed ...

\subsection{Malachi 1:11 understood as a metaphor}

An historical interpretation of verse 11 does not answer all the questions. If it is agreed that the bringing of sacrifices refers to the current situation in Jerusalem, the question arises how is it possible for a prophet such as Malachi, so deeply influenced by Deuteronomistic theology, to propose a view of the cult permitting sacrifices outside Jerusalem. This question prompted Swetnam (1969:204-205) to look in another direction and to interpret the sacrifices made outside Jerusalem in a metaphorical sense. He understands the offerings brought as a metaphor for prayer, the prayers offered by the Jews of the Diaspora, an interpretation already found in the writings of Justin (Swetnam 1969:205).

Deutsch (1987:86) is also in favour of a metaphorical interpretation of Malachi 1:11. As a literal understanding does not match the details, "one may also understand them metaphorically, as symbols 
of the genuine faith of Jews living among non-Jews". Deutsch does not elaborate on this interpretation, but it seems as if he also has the Jews of the Diaspora in mind as they are the symbols of genuine faith.

Recently, Viberg (1994:297-319) presented yet another metaphorical interpretation of verse 11 . According to him, a literal interpretation of verse 11 is highly unlikely and he therefore favours a metaphorical interpretation. Like the phrases enveloping the middle section of verse 11 should be understood as metaphors on the basis of verse 14 , the controversial phrase - and in every place incense/burnt offering is brought to my name - a pure offering — should also be understood as a metaphor. The intention of the metaphor in verses 14 and 11 is that of Yahweh's supreme authority of his rule over the world. The meaning conveyed by the metaphor in verse 14 and the two enveloping sections of verse 11 is that of rule and supremacy implying Yahweh's authority. The middle section of verse 11 elaborates on the metaphor used in the two enveloping sections. The meaning of the reawakened metaphor is that Yahweh is the great king who should be worshipped as such. Yahweh, as the supreme God, deserves the cultic recognition of all mankind. Because Yahweh is the supreme God - his name is great among the nations - he is also supreme in cultic life.

Van der Woude (1982:101) draws a similar conclusion. Malachi $1: 11$ is not about a cultic revelation of Israel's God, but about the glory and splendour of his universal kingship as is also attested in the Psalms (47:3; 48:2; 76:2; 145:3; 147:5).

\subsection{Intertextual interpretation of Malachi 1:11}

Malachi 1:11 was also subjected to an intertextual investigation (Utzschneider 1989:54-60). Utzschneider (1989:54) found that there is an intertextual link between Ezekiel 36:20 and Malachi 1:11 because certain words are only used in these two passages (של ,גדול , שמי). According to the Ezekiel text, the name of Yahweh is profaned among the nations by the Israelite exiles. According to the Malachi text the name of Yahweh is honoured among the nations because of a regular cult "in every place". This recalls Jewish sanctuaries "among the nations" so that Utzschneider (1989:57) ultimately concludes that this 
must be a reference to Diaspora Jews. According to Utzschneider (1989:86), it is possible that Yahweh was honoured in a legitimate way "among the nations", "in every place" by Jews living in various parts of the then known world.

\section{CONCLUSION}

In the course of the history of its investigation Malachi 1:11 acquired a number of meanings. The various interpretations of the text in question may mean the following:

- The offerings gentile nations brought to their gods are also worthy offerings to Yahweh.

- Proselyte Jews brought sacrifices to honour Yahweh even outside Israel.

- Jews in the Diaspora continue to bring sacrifices to Yahweh beyond Jerusalem.

- Malachi 1:11 is a prophetic vision of the Mass celebrated in the Roman Catholic Church.

- Malachi 1:11 is a prediction of a future, undefined eschatological time in the messianic era.

- Malachi 1:11 serves as a hyperbole comparing the sincere offerings of gentile nations with the malpractices in priestly circles.

- Malachi 1:11 is a metaphor denoting different meanings. It may refer to the prayers of Jews in the Diaspora; it may be a symbol of genuine faith of Jews living among non-Jews, or it may convey the meaning that Yahweh is a great king who should be worshipped as such.

- Malachi 1:11 has also been understood intertextually (Ezechiel 36 and Psalm 113 are the relevant texts) and that resulted in the meaning that Jews honoured Yahweh in the Diaspora while priests profaned his name in the Jerusalem cult.

Each of the above interpretations will have a profound effect on understanding the pericope and the book as a whole. To consider the sacrifices brought by gentiles or by Jews makes an important difference in our understanding of the passage as a whole. To interpret the 
reference to sacrifices brought as something that will happen in future is quite different from interpreting it as a reference to current conditions in Israel. Likewise, to interpret the text by means of its literary features and characteristics will also have an influence on the eventual meaning ascribed to it.

Trends in the development of exegesis can be clearly traced in this investigation. A stringent application of literary criticism (Literarkritik) will result in the scrapping of a text regarding it as a later (and unwelcome) interpolation. A less stringent historical approach and a more "evangelistic" exegesis will favour an eschatological interpretation of the text whereas church doctrine may also affect our understanding of a text. Literary investigation is less interested in historical and accurate facts and may therefore interpret a text along the lines of its literary qualities arriving at answers different from a historical interpretation. Trends in the method(s) of exegesis have an impact on the results of an exegetical investigation.

None of these interpretations can be labelled invalid. The proposed interpretations are substantiated by solid argumentation. This proves that a text has more than one valid meaning. There may be meanings that will be more likely or more convincing than others, but the less likely meaning may even add a valuable meaning(s) to a text.

The choice for a specific interpretation of a text is also reflected in its translation. (Or is it perhaps the other way around: a translation may influence the interpretation of a text?) In the case of Malachi 1:11 it is interesting to note how the KJV, NKJV and the NIV opted for an eschatological interpretation by translating the text in the future tense. The other translations opted for an understanding of the text in the circumstances current at the time when the prophet proclaimed the message.

This investigation reminds us of the relativity of interpretation. As the time differs, as our historical, sociological and philosophical contexts change, our interpretation of a text also differs. And so it happens that a text may acquire different meanings, Malachi $1: 11$ is a case in point. 


\section{BIBLIOGRAPHY}

\section{ACHTEMEIER E}

1986. Nahum - Malachi. Atlanta: John Knox. Interpretation.

\section{BOTTERWECK G J}

1960. Ideal und Wirklichkeit der Jerusalemer Priester. Auslegung von Mal. 1,610; 2,1-9. Bibel und Leben 1:100-109.

\section{BALDWIN J G}

1972. Malachi 1:11 and the worship of the nations in the Old Testament. Tyndale Bulletin 23:117-124.

1978. Haggai, Zechariah, Malachi. An introduction and commentary. Leicester: InterVarsity Press. TOTC.

\section{CALvin J}

1979. Commentaries on the Twelve Minor Prophets. Volume fifth. Zechariah and Malachi. Michigan: Baker Book House.

\section{DeISSLER A}

1988. Zwölf Propheten III. Zefanja Haggai Sacharja Maleachi: Echter Verlag. NEB.

\section{DEUTSCH R R}

1987. Malachi — A call to obedience. Grand Rapids: W.B. Eerdmans. ITC.

\section{ELLIGER K}

1975. Das Buch der zwölf kleinen Propheten II. Göttingen: Vandenhoeck \& Ruprecht. 7. durchgesehene Auflage. ATD.

\section{FREY H}

1963. Das Buch der Kirche in der Weltwende. Die kleinen nachexilischen Propheten. Stuttgart: Calwer. BAT.

\section{GLAZIER-MCDONALD B}

1987. Malachi the divine messenger. Atlanta: Scholars Press. SBLDS 98.

\section{HORST F}

1964. Die zwölf kleinen Propheten — Nahum bis Maleachi. Tübingen: J.C.B. Mohr (Paul Siebeck). 3. Auflage. HAT.

\section{KRIEG M}

1993. Mutmassungen über Maleachi. Eine Monographie. Zürich: Theologischer Verlag. AThANT 80.

\section{Merrill E H}

1994. An exegetical commentary. Haggai, Zechariah, Malachi. Chicago: Moody Press.

\section{Petersen D L}

1995. Zechariah 9-14 and Malachi. A commentary. Louisville: Westminster John Knox Press. OTL. 


\section{REHM M}

1961. Das Opfer der Völker nach Mal. 1:11. In: H. Gross \& F. Mussner (eds.),

Lex tua Veritas, Festschrift H. Junker (Trier: Paulinus), pp. 193-208.

\section{REVENTLOW H G}

1993. Die Propheten Haggai, Sacharja und Malachi. Göttingen: Vandenhoeck \& Ruprecht. ATD 25/2.

\section{RUDOLPH W}

1976. Haggai - Sacharja 1-8 - Sacharja 9-14 - Maleachi. Gerd Mohn: Gütersloher Verlagshaus. KAT 13/4.

\section{SмIтH G A}

1943. The Book of the Twelve Prophets. Vol. II. Grand Rapids: Baker Books.

\section{SMITH J M P}

1980. A critical and exegetical commentary on the book of Malachi. Edinburgh: T\&T Clark. ICC.

\section{SMITH R L}

1984. Micah - Malachi. Waco: Word Books. WBC 32.

\section{SWETNAM J}

1969. Malachi 1:11: an interpretation. CBQ 31:200-209.

\section{STUART D}

1998. Malachi. In: T.E. McComiskey (ed.), The minor prophets. An exegetical and expository commentary (vol. 3) (Grand Rapids: Baker Books).

\section{UTZSCHNEIDER H}

1989. Künder oder Schreiber? Eine These zum Problem der "Schriftprophetie" auf Grund von Maleachi 1,6-2,9. Frankfurt am Main: Peter Lang. BEATA 19.

\section{VAN DER WOUde A S}

1982. Haggai Maleachi. Nijkerk: Callanbach. POT.

\section{Verhoef P A}

1966. Some notes on Malachi 1:11. Biblical Essays (Pro-Rege: Potchefstroom), pp. 163-172.

1987. The Books of Haggai and Malachi. Grand Rapids: W. B. Eerdmans. NICOT.

VIBERG A

1994. Wakening a sleeping metaphor: a new interpretation of Malachi 1:11. Tyndale Bulletin 45(2):297-319.

\section{VRIEZEN TH C}

1975. How to understand Malachi 1:11. In: J.I. Cook (ed.), Grace upon grace, Festschrift J. Kuyper (Eerdmans: Grand Rapids), pp. 128-136. 
Acta Theologica Supplementum 6

\section{WeYDE K W}

2000. Prophecy and teaching. Prophetic authority, form problems and the use of traditions in the Book of Malachi. Berlin: Walter de Gruyter. BZAW 288.

Keywords

Old Testament exegesis

Malachi 1:11

Historical interpretation

Literary interpretation

Intertextual interpretation
Trefwoorde

Eksegese van die Ou Testament

Maleagi 1:11

Historiese interpretasie

Literêre interpretasie

Intertekstuele interpretasie 